$\xi_{p}$

\title{
Influence of Project Type, Location and Area towards Construction Delay: a Review on Significance Level of Delay Factors
}

\author{
Mohd Zakwan Ramli ${ }^{1 *}$, Marlinda Abdul Malek ${ }^{2}$, Baizura Hamid ${ }^{3}$, Nursyadzatul Tasnim Roslin ${ }^{4}$, Mohd Eqwan \\ Mohd Roslan ${ }^{5}$, Shuhairy Norhisham ${ }^{6}$ and Mohd Firdaus Mohd ${ }^{7}$ \\ ${ }^{l}$ College of Engineering, Universiti Tenaga Nasional, Kajang, Selangor, Malaysia. \\ ${ }^{2}$ Institute of Energy Policy Research (IEPRe), Universiti Tenaga Nasional, Kajang, Selangor, Malaysia. \\ ${ }^{3}$ Jabatan Kejuruteraan Awam, Pusat Pengajian Diploma, Universiti Tun Hussein Onn Malaysia, Pagoh, Johor, Malaysia. \\ ${ }^{4}$ Cawangan Kejuruteraan Awam dan Struktur, Jabatan Kerja Raya, Kuala Lumpur, Malaysia. \\ *Corresponding author E-mail: zakwan@uniten.edu.my
}

\begin{abstract}
Construction delay is something that is inevitable, which is why it is a global problem faced by the construction industry. This paper highlighted the characteristics that influenced construction delay but usually ignored in many researches. Project type, location, and area are the characteristics that are not concerned by many. Therefore, this study is reviewing literature in construction delay to find the significance of the influence of the mentioned characteristics. It was found that there is a significant influence of the project type and location towards construction delay problems, where different project type experienced different delay causes. This was probably due to different difficulties faced by each of project type. Project location characteristic also undergoes the same pattern; which is within the same region, the same pattern of major cause was identified. Meanwhile, the insignificant level of influence was identified for the construction area characteristic. This was probably due to the readiness and awareness of contractor regarding the site condition before the construction start. It is expected that this study will open up more discussions regarding these characteristics in the future.
\end{abstract}

Keywords: causes of construction delay; construction delay; construction projects; delay factors pattern; project type, location, and area

\section{Introduction}

One of the key players in a developing country is the construction industry. It is undeniable that the industry has existed for a long time in human civilization. However, the industry is often plagued with the same problem which is construction delay. Delays create adverse effects on many parties such as cost, time, quality and also safety [1]. These effects give a bad impact on the economic development of a country.

To overcome such problems, numerous root causes have been identified in lot of studies. By acknowledging the causes or factors, preventive measures can be taken to avoid the recurrence of this problem. However, it has been noticed that most literature does not consider several characteristics that are likely to have an influence on the construction delay problem. The intended characteristics are project type, location and area. For example, projects with the same project type would probably have the same root of causes in delay problem. If these characteristics ignored, the actual cause of the problem cannot be precisely identified. It seems to be inaccurate if each construction with different project type, location or area is compared together as they faced different difficulties and challenges.

This paper's objective, therefore, intends to gather as much as possible previous studies to evaluate the influence of project type, location and area towards the construction delay, as well as its significance. It is expected that its findings can be guidance for future research of construction delay.

\section{Delay Factors}

Before discussing any further, we need to understand the delay term in construction industry. Definition of delay according to [2] is an extension of time or time overrun in completing a project. Therefore, when a project is time extended it will cause additional cost. Delay in a construction project brings serious problems to the parties involved, which are: client, consultant, and contractor. For the client, they will encounter low productivity, profit loss, increasing reliance on available facilities and etc. As for the contractor, they will have to overcome problems such as higher costs, longer work duration, increase in material, equipment and labour cost [3].

Through previous literature, there are various factors which cause delay in construction. These factors are categorized according to their respective relevance [4]:

a) Factors related to consultant

b) Factors related to contractor

c) Factors related to design

d) Factors related to equipment

e) Factors related to external

f) Factors related to labour

g) Factors related to material

h) Factors related to owner 
i) Factors related to project

Factors related to consultant are such as; delay in approving changes, lack of experience, inaccurate site investigation, etc. While factors relate to contractor are; poor state of commitment in site supervision and management, inefficient of project scheduling and planning, inadequate experience, etc. Design related factors are; design changes by owner, design errors, insufficient data collection and survey, etc. Factors related to equipment are equipment shortages, recurrent equipment malfunctions, problems in allocating equipment, etc. Meanwhile, factors relate to external are; global financial crisis, delay in providing services from utilities, unexpected surface and subsurface conditions, etc. Labour related factors are; shortages problem, inexperienced workers, low productivity, etc. Factors related to the material are; shortage of materials, late delivery, unreliable suppliers, etc. As for owner related factors are; delay in making progress payments, change orders, slow decision-making process, etc. Project related factors are; the level of project difficulties, short contract duration, the existence of legal disputes between involved parties, etc.

Literature on the identification of construction delay factors is extensive. In this review, several studies were discussed to understand the pattern of their findings in terms of the project type, location and area.

\section{Literature Review}

In order to understand the development of study in construction delay, previous literature has been gathered. The literature comprises several of study background.

Recently, [5] had identified the primary factors of delay in the Portuguese construction. The result from the survey shows several factors that caused the delay: change of orders, slow in decisionmaking process, unreasonable of given time frame, contractor's financial problem, specification of contract is unclear, and weakness process of bidding and contract award.

[6] conducted a research to find the causes of road construction delays in Egypt by studying the list of causes of different types of construction, different periods and different countries gathered from the literature. A questionnaire survey and interview were then performed and found 239 delay causes as the basis of the study. The study concluded that there is no causes can be considered as the most or the least influenced cause in delay problem.

Another research of delay in road construction done by [7], claimed that Jordan's road construction main problem is the terrain and weather conditions. The conditions are trouble in getting to the work site, the type of work, issues in acquiring the land, a setback for utility relocation, and the shortages of civil services. Apart from that, variation of orders, and availability of labour also among the major factors listed.

Meanwhile, delay causes in the construction projects of oil and gas processing facilities in Oman have been investigated by [8]. Seven major factors were identified: (1) lack of site supervision and management by the contractors, (2) problems with the subcontractors, (3) shortcomings in planning and scheduling by the contractors, (4) contractors do not manage schedules properly, (5) delay in materials' delivery, (6) ineffective communication among the involved parties, and (7) faulty interactions with vendors in the stage of engineering and procurement.

The causes of delay in gas pipeline projects in Iran were identified in a study by [9] in 2013. It is also stated that there is an exceptional delay in most of the gas pipeline projects. The result revealed ten major delay factors, they are: material obtained by import, unrealistic project duration, material characteristics must strictly follow customer requirements, acquisition of land, change orders, methods selection by contractor, late payment received by contractor, issues in obtaining permits, delay in supplier works, and poor contractor's cash flow.
[10] identified the most important delay factors on the construction in Turkey. They are; contractor's lack of experience, weaknesses in planning and scheduling, deficient of site management and supervision, design changes during construction, and delay in material delivery.

Factors of delay in public construction projects of Jordan were studied by [1]. The results revealed that (1) inadequate qualification of consultants, engineers and staff, (2) poor planning and scheduling, and also (3) extreme weather conditions, were the main factors contribute to delay in the public projects.

[11] studied delay factors in the Turkey construction industry. They found the most predominant factor is changes of design and material, followed by delay payment to contractor, client's cash flow problem, contractor's financial issue, and poor labour productivity. The study also claimed that financial problems were raised from owners and main contractors considering that macroeconomic atmosphere notably influenced on the situations.

[12] investigate the cause of delays in road construction projects in West Bank, Palestine. From the survey, five major delay causes were identified; current political situation, limited movement due to the divided West Bank, project awarded to the lowest bidder, owner delayed payment to contractor, and equipment shortages.

To determine the major causes of delay in Malaysian construction industries, [13] had conducted a survey. The outcome obtained was; productivity of workers, materials delivery to working site, escalation of material price, lack of equipment, and financial problem faced by contractor and owner. They also explained that the importance order was changed compared to the list of causes from the literature review.

Receiving late payments, contractors and clients facing financial problems, contract being modified, difficulties in economic were found to be the top five causes in Zambia's road construction delays. This finding was reported by [14].

Mentioned above are among of the reviewed literature to observe the pattern of delay causes in construction regarding of its project type, location, and area. All of the selected studies were presented in a tabular form to observe the significance level of that specified criteria.

\section{Influence of Project Type}

In construction, project type is divided into three sectors: building, infrastructure and industrial. Building construction includes residential and non-residential. While infrastructure construction comprises of large public works, highways, water or wastewater, dams, railways, utility distribution, and bridges. Industrial construction includes process chemical, refineries, power generation, manufacturing plants, and mills.

Through literature, one can realize the lack of studies which emphasize on the influence of project type towards construction delay. Thus, there is a need for reviewing prior studies based on the issue mentioned above. Table 1 shows major causes of delay in the construction industry according to the type of project.

It can be seen that the major delay causes for building project are changes of design during construction/change orders, followed by delays in contractor's payment by owner. Meanwhile, for the infrastructure project, the main cause of the delay is late payment by owner. As for the industrial project, the primary causes are late delivery of materials problems, problems related to subcontractors, and poor site management and supervision.

It was found that changing order by owner during construction is a common cause for building project type in most studies reviewed. This is supported by [15] and [16], who stated it as the most important delay factor. From [17], which is related to delayed high-rise building projects in Thailand, changes order is suggested as the most likely to occur in private projects. They claimed that it probably results from the private owners' habit of changing plans due to the economic shifting, to fulfil customers' demand or for 
Table 1: Major causes of delay in the construction industry according to the type of project.

\begin{tabular}{|c|c|c|c|c|c|c|c|c|c|c|c|c|c|c|c|c|c|c|c|}
\hline \multirow[b]{2}{*}{$\begin{array}{l}\text { Resear } \\
\text { chers }\end{array}$} & \multirow[b]{2}{*}{$\begin{array}{c}\text { Coun } \\
\text { try }\end{array}$} & \multirow[b]{2}{*}{$\begin{array}{c}\text { Project } \\
\text { Type }\end{array}$} & \multicolumn{17}{|c|}{ Causes of delay } \\
\hline & & & $\begin{array}{c}\text { Poor } \\
\text { site } \\
\text { manag } \\
\text { ement } \\
\text { and } \\
\text { supervi } \\
\text { sion }\end{array}$ & $\begin{array}{c}\text { Problem } \\
\text { s related } \\
\text { to } \\
\text { subcontr } \\
\text { actors }\end{array}$ & $\begin{array}{c}\text { Poor } \\
\text { planni } \\
\text { ng } \\
\text { and } \\
\text { sched } \\
\text { uling }\end{array}$ & $\begin{array}{c}\text { Inade } \\
\text { quate } \\
\text { contra } \\
\text { ctor } \\
\text { experi } \\
\text { ence }\end{array}$ & $\begin{array}{c}\text { Late } \\
\text { deliv } \\
\text { ery } \\
\text { of } \\
\text { mate } \\
\text { rials }\end{array}$ & $\begin{array}{c}\text { Design } \\
\text { change } \\
\mathrm{s} \\
\text { during } \\
\text { constru } \\
\text { ction/ } \\
\text { Change } \\
\text { orders }\end{array}$ & $\begin{array}{l}\text { Incom } \\
\text { plete } \\
\text { or } \\
\text { impro } \\
\text { per } \\
\text { design }\end{array}$ & $\begin{array}{c}\text { Contra } \\
\text { ctor's } \\
\text { financi } \\
\text { al } \\
\text { difficul } \\
\text { ties }\end{array}$ & $\begin{array}{c}\text { Delays } \\
\text { in } \\
\text { contra } \\
\text { ctor's } \\
\text { payme } \\
\text { nt by } \\
\text { owner }\end{array}$ & $\begin{array}{c}\text { Shorta } \\
\text { ge of } \\
\text { materi } \\
\text { al/ } \\
\text { equip } \\
\text { ment/ } \\
\text { manp } \\
\text { ower }\end{array}$ & $\begin{array}{c}\text { Unfor } \\
\text { eseen } \\
\text { geolog } \\
\text { ical } \\
\text { condit } \\
\text { ions }\end{array}$ & $\begin{array}{c}\text { Difficu } \\
\text { lties in } \\
\text { obtaini } \\
\text { ng } \\
\text { permit } \\
\text { s and } \\
\text { excessi } \\
\text { ve } \\
\text { bureau } \\
\text { cracy }\end{array}$ & $\begin{array}{c}\text { Weat } \\
\text { her } \\
\text { condi } \\
\text { tion }\end{array}$ & $\begin{array}{l}\text { Slow } \\
\text { decis } \\
\text { ion- } \\
\text { maki } \\
\text { ng } \\
\text { proc } \\
\text { ess }\end{array}$ & $\begin{array}{c}\text { Econo } \\
\text { mic } \\
\text { proble } \\
\text { ms } \\
\text { (e.g., } \\
\text { inflati } \\
\text { on, } \\
\text { fluctu } \\
\text { ation) }\end{array}$ & $\begin{array}{c}\text { Poor } \\
\text { contrac } \\
t \\
\text { manag } \\
\text { ement }\end{array}$ & $\begin{array}{c}\text { Poor } \\
\text { labour } \\
\text { produc } \\
\text { tivity }\end{array}$ \\
\hline $\begin{array}{l}{[10]} \\
,[18]\end{array}$ & $\begin{array}{c}\text { Turk } \\
\text { ey }\end{array}$ & $\begin{array}{c}\text { Buildin } \\
\mathrm{g}\end{array}$ & $\bullet$ & & $\bullet$ & $\bullet$ & $\bullet$ & $\bullet$ & & & & & & & & & & & \\
\hline$[11]$ & $\begin{array}{c}\text { Turk } \\
\text { ey }\end{array}$ & $\begin{array}{c}\text { Buildin } \\
\mathrm{g}\end{array}$ & & & & & & • & & $\bullet$ & $\bullet$ & & & & & & & & $\bullet$ \\
\hline [19] & $\begin{array}{c}\text { Turk } \\
\text { ey }\end{array}$ & $\begin{array}{c}\text { Buildin } \\
\mathrm{g}\end{array}$ & & & & & & & & $\bullet$ & $\bullet$ & $\bullet$ & & & & & & & \\
\hline$[20]$ & $\begin{array}{c}\text { Saudi } \\
\text { Arabi } \\
\mathrm{a}\end{array}$ & $\begin{array}{c}\text { Buildin } \\
\mathrm{g}\end{array}$ & & & & & $\bullet$ & & $\bullet$ & & $\bullet$ & & & & & & & & \\
\hline$[15]$ & $\begin{array}{c}\text { Saudi } \\
\text { Arabi } \\
\mathrm{a}\end{array}$ & $\begin{array}{c}\text { Buildin } \\
\mathrm{g}\end{array}$ & & & & & & $\bullet$ & • & & $\bullet$ & & & & & & & & \\
\hline$[21]$ & $\begin{array}{c}\text { Saudi } \\
\text { Arabi } \\
\mathrm{a}\end{array}$ & $\begin{array}{c}\text { Buildin } \\
\mathrm{g}\end{array}$ & & & & & & $\bullet$ & • & $\bullet$ & $\bullet$ & & & & & • & & & \\
\hline$[22]$ & $\begin{array}{c}\text { Jorda } \\
n\end{array}$ & $\begin{array}{c}\text { Buildin } \\
\mathrm{g}\end{array}$ & & & & & & $\bullet$ & & $\bullet$ & & $\bullet$ & & & & & & & \\
\hline$[23]$ & $\begin{array}{c}\text { Jorda } \\
n\end{array}$ & $\begin{array}{c}\text { Buildin } \\
\mathrm{g}\end{array}$ & & & & & $\bullet$ & $\bullet$ & $\bullet$ & & & & $\bullet$ & & $\bullet$ & & $\bullet$ & & \\
\hline$[24]$ & $\begin{array}{c}\text { Kuw } \\
\text { ait }\end{array}$ & $\begin{array}{c}\text { Buildin } \\
\mathrm{g}\end{array}$ & & & & & & $\bullet$ & & & $\bullet$ & & & & & & & & \\
\hline$[17]$ & $\begin{array}{c}\text { Thail } \\
\text { and }\end{array}$ & $\begin{array}{c}\text { Buildin } \\
\mathrm{g}\end{array}$ & & & & & $\bullet$ & & $\bullet$ & & & $\bullet$ & & & & $\bullet$ & & & \\
\hline$[16]$ & $\begin{array}{c}\text { Mala } \\
\text { ysia }\end{array}$ & $\begin{array}{c}\text { Buildin } \\
\mathrm{g}\end{array}$ & & & & & & & & & $\bullet$ & $\bullet$ & & & & & & & \\
\hline$[25]$ & $\begin{array}{l}\text { Indo } \\
\text { nesia }\end{array}$ & $\begin{array}{c}\text { Buildin } \\
\mathrm{g}\end{array}$ & & & $\bullet$ & & & $\bullet$ & & & & & & & & & & & • \\
\hline$[26]$ & \begin{tabular}{|c|} 
Unite \\
$\mathrm{d}$ \\
State \\
$\mathrm{s}$
\end{tabular} & $\begin{array}{c}\text { Buildin } \\
\mathrm{g}\end{array}$ & & & & & & $\bullet$ & $\bullet$ & & & & & $\bullet$ & & & & & \\
\hline $\begin{array}{l}\text { Frequ } \\
\text { ency }\end{array}$ & & & 1 & $\mathbf{0}$ & 2 & 1 & 4 & 9 & 6 & 4 & 7 & 4 & 1 & 1 & 1 & 2 & 1 & $\mathbf{0}$ & 2 \\
\hline [12] & \begin{tabular}{|c|} 
Pales \\
tine
\end{tabular} & $\begin{array}{c}\text { Infrastr } \\
\text { ucture }\end{array}$ & & & & & & & & & $\bullet$ & $\bullet$ & & $\bullet$ & & & & & \\
\hline$[27]$ & $\begin{array}{c}\text { Saudi } \\
\text { Arabi } \\
\mathrm{a}\end{array}$ & $\begin{array}{c}\text { Infrastr } \\
\text { ucture }\end{array}$ & & & & & & & & & • & & $\bullet$ & $\bullet$ & & & & & \\
\hline$[14]$ & $\begin{array}{c}\text { Zam } \\
\text { bia }\end{array}$ & $\begin{array}{c}\text { Infrastr } \\
\text { ucture }\end{array}$ & & & & & & $\bullet$ & & & $\bullet$ & & & & & • & & & \\
\hline$[28]$ & $\begin{array}{c}\text { Niger } \\
\text { ia }\end{array}$ & $\begin{array}{c}\text { Infrastr } \\
\text { ucture }\end{array}$ & & & & & & & & & $\bullet$ & $\bullet$ & & & & & • & • & \\
\hline [29] & $\begin{array}{c}\text { Ghan } \\
\text { a }\end{array}$ & $\begin{array}{c}\text { Infrastr } \\
\text { ucture }\end{array}$ & & & & & & & & $\bullet$ & $\bullet$ & & $\bullet$ & & & & $\bullet$ & $\bullet$ & \\
\hline $\begin{array}{l}\text { Frequ } \\
\text { ency }\end{array}$ & & & $\mathbf{0}$ & $\mathbf{0}$ & $\mathbf{0}$ & $\mathbf{0}$ & $\mathbf{0}$ & 1 & $\mathbf{0}$ & 1 & 5 & 2 & 2 & 2 & $\mathbf{0}$ & 1 & 2 & 2 & $\mathbf{0}$ \\
\hline [8] & $\begin{array}{c}\text { Oma } \\
\mathrm{n}\end{array}$ & $\begin{array}{c}\text { Industri } \\
\text { al }\end{array}$ & $\bullet$ & $\bullet$ & $\bullet$ & & $\bullet$ & & & & & & & & & & & & \\
\hline [9] & Iran & $\begin{array}{c}\text { Industri } \\
\text { al }\end{array}$ & & $\bullet$ & & & $\bullet$ & & & & & & $\bullet$ & & & & & & \\
\hline$[30]$ & UAE & $\begin{array}{c}\text { Industri } \\
\text { al }\end{array}$ & $\bullet$ & & & • & $\bullet$ & & & & & $\bullet$ & & & & & & $\bullet$ & \\
\hline $\begin{array}{l}\text { Frequ } \\
\text { ency }\end{array}$ & & & 2 & 2 & 1 & 1 & 3 & $\mathbf{0}$ & $\mathbf{0}$ & $\mathbf{0}$ & $\mathbf{0}$ & 1 & 1 & $\mathbf{0}$ & $\mathbf{0}$ & $\mathbf{0}$ & $\mathbf{0}$ & 1 & $\mathbf{0}$ \\
\hline
\end{tabular}

Marketing purpose. Moreover, the study indicated that change order by owners is primarily due to the appearance and adding market value to the building. The request for changes, however, occurs suddenly, which is usually in short notice. Therefore, the impact is on the contractor's plan which gives influence to the time of project completion. In fact, [22] stated that many experts agreed; tremendous implications on the performance of project financial with excessive changing orders. In addition, a research on public construction project delays in Turkey suggested that the predominant cause of many construction owners ordered extra work is because putting insufficient effort and time in the preconstruction stage, such as study on feasibility, design and site survey [19].

Late payment to the contractor is found to be among the main reason of delays in building and infrastructure projects. [17] claimed that most of the building projects they had surveyed in 
Thailand are commercial ventures, where owners use the sales profits to finance construction. But, when there is a project that fails to generate income, it causes the owner to experience cash flow difficulties, which results in a delayed payment to the contractor. Meanwhile, [14] stated that road construction project in Zambia is facing time overrun too because of late payment by client. Also, it can be noticed that studies on delay problem of government-funded projects put blame on late payment to the contractor as the main reason in overscheduled projects. Such as in Turkey, the difficulties for contractors in receiving payment from agencies are because of the agencies' budgets is so much depending on the cash flow from the national budget. Thus, inadequate funds allocated for the agencies' project investments increasing the projects' duration [19]. This situation was found to be similar to the [20] findings of the delays in Saudi Arabia's public projects. Underfunding by the Saudi Ministry of Finance is the main reason in the public project delays. Besides that, too many departments reviewing contractor's payment also giving effect, seeing that it creates a long process. This was agreed by [31], 31.25\% of the respondents preferred the government as their clients because of fewer conflicts in the payment amount, whereas $18.75 \%$ chose the private sector because it took longer time in payment release due to its normal procedures.

For the industrial type of construction, problems with subcontractors seem to be the main reason for project delays. As in [8], studied in Oman's oil and gas construction projects discovered that inadequate experience or capability of subcontractors contributing to the major cause of delays. Generally, most of the oil and gas constructions are large projects and the involvement of many subcontractors is inevitable. Therefore, unskilled subcontractors will slow down the progress of the project and sometimes create a new problem for the main contractors. As the oil and gas construction projects are complex, highly knowledgeable workers are required in the projects. [32] stated that high dependency on subcontracting expose projects to high risk of delays. Apart from the knowledge and skills issues, communication is also linked to subcontractors' problems where lack of communication between parties involved [33]. There is also a possibility that slow mobilization is the cause of the subcontractor-related problem. This is due to the tough challenge faced by subcontractors in transporting equipment and workers for oil and gas projects due to its site condition.

Materials are among three important sources in any construction beside of manpower and machines. Its availability needs to be ensured by contractors throughout the project whenever it is needed as shortages can cause delay. In [32], they explained that material delivery delay to construction site is a frequent contributor cause for projects in developing countries. They also stated that this material delivery delay problem is caused by organisation's weakness, default by suppliers, regulations set by government, and delay in transportation. Like the African countries, it has been reported that delay in material delivery is relating to the issues of clearing customs [34]. This is due to the regulatory issues or refusal in bribery, where the equipment can suffer retention at customs up to months. It is an indication that this cause is endemic to countries with high geopolitical risks. Furthermore, this cause of delay reportedly ranked highest within industrial and power projects since this type of projects relied on importing materials and equipment in large quantities, making them more susceptible. The unavailability of materials from minor items to the main components could delay the progress of the project. According to [8], material delivery delay in oil and gas construction is due to the construction sites situated in the remote area.

From the frequency method, we can see that different project type experienced different delay causes. This was probably due to different difficulties faced by each project type.

\section{Influence of Project Location}

There are some studies claimed that delay in construction of a project depends on the location where the project is situated. This is supported by [32] which stated delays in construction projects can be country-specific whereas project characteristics are regionspecific. [6] claimed each study has different causes. Country, location and project type are causes and groups causing delays. Also stated, there are no root causes which give the most or the least influence in delays.

There are factors that may be associated with the location of the project, which are weather conditions, material shortages in the market, economic conditions such as currency and inflation rate, changes in regulations and policies, and public agency related matters (roads, utilities, public services, etc.) [16].

An interesting article on oil and gas megaprojects discussed cost overrun and delay problems in the industry [35]. Fascinatingly, the highest region facing delay problems in the oil and gas industry is the Middle East region countries with $87 \%$, compared to Africa $82 \%$, Asia Pacific $80 \%$, Europe $74 \%$, Latin America $71 \%$, and $55 \%$ North America. The region with the highest delay problems is the world's top oil producers! Factors contributing to this statistical information, which related to the project location are regulatory challenges (delay caused by regulations and uncertainty of policy, and lack of infrastructure), and challenges in geopolitics issues (diplomatic and security issues, uncertainty in financial and supplier market, and disruption in civil and workforce). A study of delay in road construction project in Palestine conducted by [12] proves that the geopolitical condition of the country has a major impact in their construction industry, particularly in the road project. This finding strengthens the fact on how the location of the project gives influence to the delay causes.

Table 2 indicates major causes of delay in the construction industry according to their region. A study revealed that within the same country, different projects can be experienced different causes of delay [36]. This statement explained regarding the frequency distribution of certain causes according to certain regions in the table.

As we can see in Middle East Asia the major factors are; late payment to contractor by owner, changes of design during construction/change orders, incomplete or improper design, as well as contractors facing financial difficulties. In East Asia, the most important causes are; shortcomings in the site coordination and supervision, and unforeseen geological conditions. It is followed by bad planning and scheduling, and less experienced contractor. In contrast, for South East Asia, the primary cause is poor planning and scheduling. Followed by are design with incomplete or improper issues, shortage of material/equipment/ manpower, and delay in contractor's payment by owner. Meanwhile, West Africa suffered from delays caused by delays in contractor's payment by owner, economic problems, and contractor's financial difficulties, shortage of material/equipment/ manpower, and poor contract management. In North America, a design change during construction/change orders is the main delay factors. After that, weather conditions came second.

Table 2: Major causes of delay in the construction industry according to region (location).

\begin{tabular}{|c|c|c|c|c|c|c|c|c|c|c|c|c|c|c|c|c|c|c|c|}
\hline \multirow[b]{2}{*}{$\begin{array}{l}\text { Resear } \\
\text { chers }\end{array}$} & \multirow[b]{2}{*}{$\begin{array}{c}\text { Coun } \\
\text { try }\end{array}$} & \multirow[b]{2}{*}{$\begin{array}{c}\text { Regi } \\
\text { on }\end{array}$} & \multicolumn{17}{|c|}{ Causes of delay } \\
\hline & & & \begin{tabular}{|c} 
Poor \\
site \\
manage \\
ment \\
and \\
supervi
\end{tabular} & $\begin{array}{l}\text { Proble } \\
\text { ms } \\
\text { related } \\
\text { to } \\
\text { subcont } \\
\text { ractor }\end{array}$ & $\begin{array}{c}\text { Poor } \\
\text { planni } \\
\text { ng } \\
\text { and } \\
\text { sched } \\
\text { uling }\end{array}$ & \begin{tabular}{|c|} 
Inade \\
quate \\
contra \\
ctor \\
experi \\
ence
\end{tabular} & \begin{tabular}{|l} 
Late \\
deliv \\
ery \\
of \\
mate \\
rials
\end{tabular} & $\begin{array}{c}\text { Design } \\
\text { change } \\
\mathrm{s} \\
\text { during } \\
\text { constru } \\
\text { ction/ }\end{array}$ & \begin{tabular}{|c|} 
Incom \\
plete \\
or \\
impro \\
per \\
design
\end{tabular} & \begin{tabular}{|c} 
Contra \\
ctor's \\
financi \\
al \\
difficul \\
ties
\end{tabular} & $\begin{array}{c}\text { Delays } \\
\text { in } \\
\text { contra } \\
\text { ctor's } \\
\text { payme } \\
\text { nt by }\end{array}$ & $\begin{array}{c}\text { Shorta } \\
\text { ge of } \\
\text { materi } \\
\text { al/ } \\
\text { equip } \\
\text { ment/ }\end{array}$ & \begin{tabular}{|c|} 
Unfor \\
eseen \\
geolog \\
ical \\
conditi \\
ons
\end{tabular} & $\begin{array}{c}\text { Difficu } \\
\text { lties in } \\
\text { obtaini } \\
\text { ng } \\
\text { permit } \\
\text { s and }\end{array}$ & $\begin{array}{l}\text { Weat } \\
\text { her } \\
\text { condi } \\
\text { tion }\end{array}$ & \begin{tabular}{|c|} 
Slow \\
decis \\
ion- \\
maki \\
ng \\
proce
\end{tabular} & $\begin{array}{c}\text { Econo } \\
\text { mic } \\
\text { proble } \\
\text { ms } \\
\text { (e.g., } \\
\text { inflati }\end{array}$ & $\begin{array}{c}\text { Poor } \\
\text { contrac } \\
\mathrm{t} \\
\text { manage } \\
\text { ment }\end{array}$ & $\begin{array}{c}\text { Poor } \\
\text { labour } \\
\text { produc } \\
\text { tivity }\end{array}$ \\
\hline
\end{tabular}




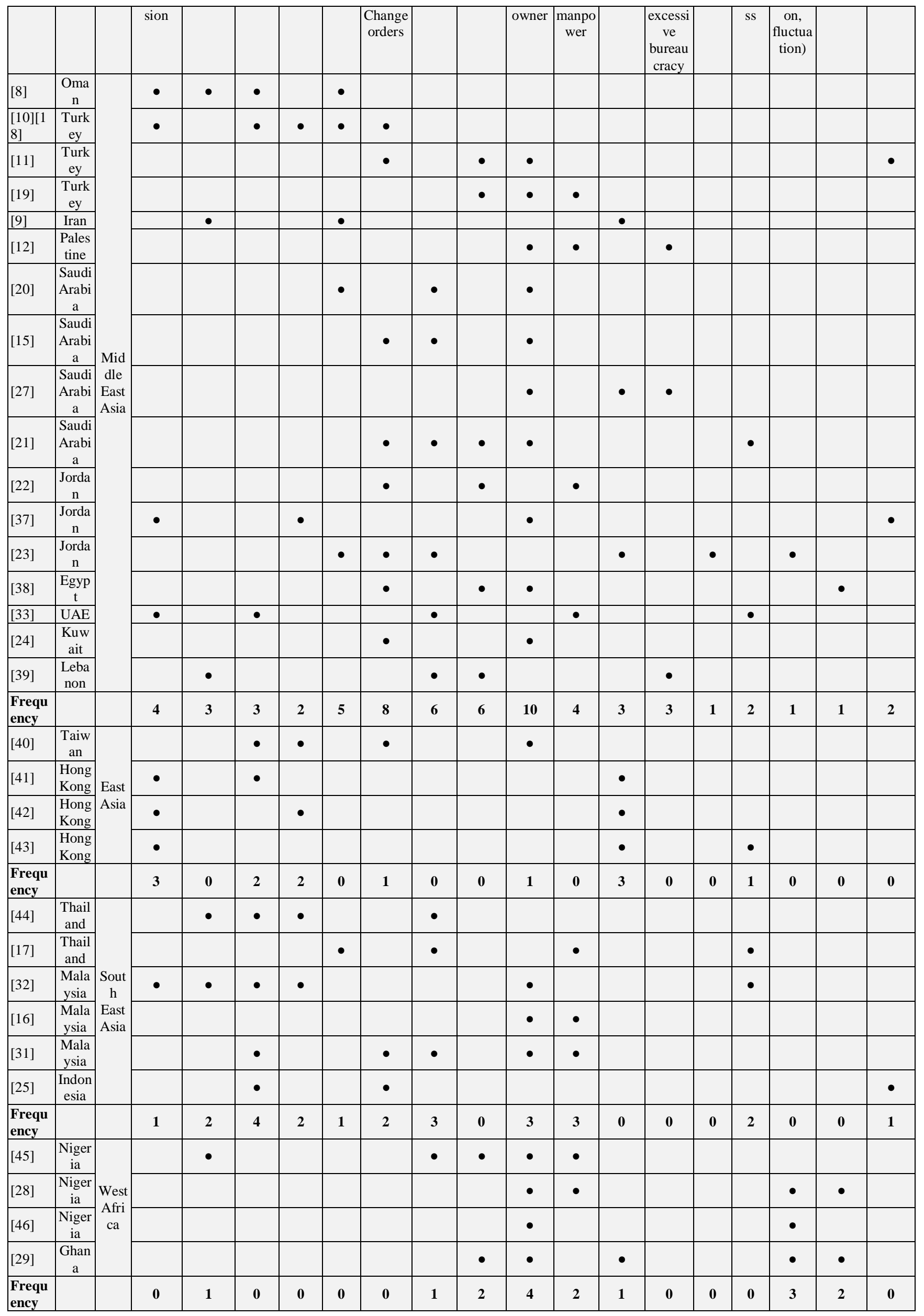




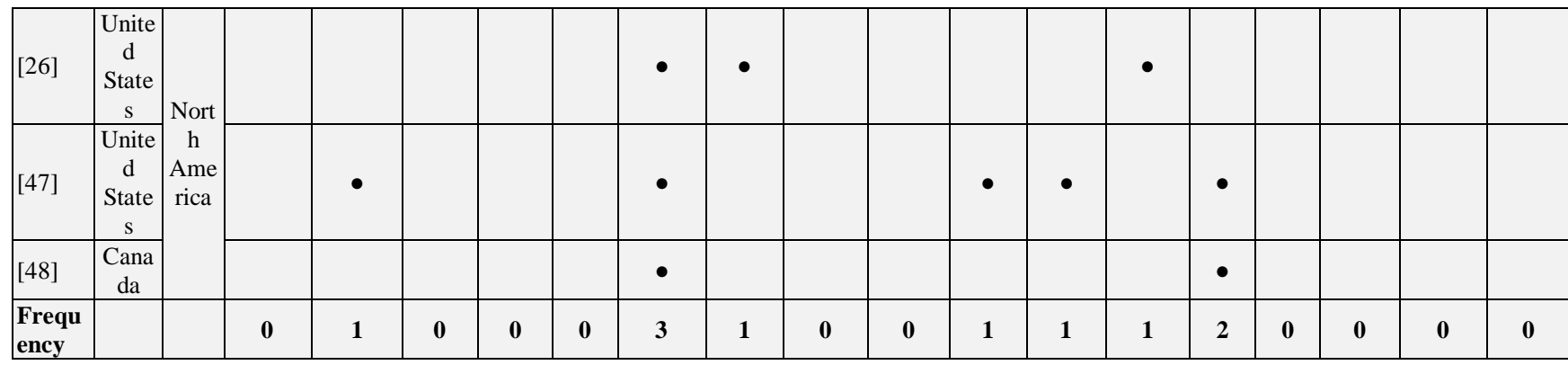

The differences were probably due to the national culture which claimed by some researchers. [49] wrote that different cultures will have different time perception. Like in western cultures (e.g., the U.S. and the Anglo-Saxon), one cannot accept to be idling because the time is viewed as linear. Contrarily, in eastern cultures (e.g., India and Asian countries), the time is not linear, but as cyclic. This is where they think that in the future, the same opportunities or risks will appear again. Therefore, one with eastern cultures do not prefer sudden decisions or to treat a current deal on its present merits. Meanwhile, [19] found that in Turkey, the non-skilled workers are mostly villagers. They go back to their villages during harvesting time and this situation caused difficulty for contractors to maintain constant activities on the sites.

As for project location characteristics, it can be seen that within a region, they can be experienced almost the same pattern of major cause. Furthermore, the common causes faced by most regions are; late payment to contractors and design changes during construction.

\section{Influence of Project Area}

Project area can be attributed to site condition, environmental condition, and topographical condition. In most of the studies regarding delays in construction, project area is the least topic found in the literature. This was probably due to its behaviour which is predictable in most projects' situation. Site conditions include traffic situations, problems with storage, site location and also accidents on site. Sites located in the city are normally disrupted by the traffic condition; therefore, a preliminary and orderly plan is very crucial. Even for a remote site location, they have their own constraint which is the distance to transport sources. Storage problems are closely related to delay in material delivery because the equipment and material need to be stored away from the sites.

[39] claimed that in each project, the site conditions are ranked low because every party are able to adapt to the existing situations. From a survey of 130 projects, [23] found that weather condition and site condition are among major causes of delay in Jordan. The site condition factors can give influence to the late delivery of materials due to the difficulties in transportation. [6] surveyed road construction delays in Egypt and listed out importance index accordance to group-related respectively. The site-related group was ranked at $8^{\text {th }}$ (refer to Table 3 ).

A survey by [15] on different types of projects in Saudi Arabia was performed. Only the respondents from the owner group chose the subsurface conditions (type of soil, existing of utilities, high water table, etc.) as one of the delay causes. Moreover, it was ranked at $9^{\text {th }}$ place (refer to Table 4) which indicates it was less important in a project delay. Meanwhile, [7] stated that terrain condition is one of the reasons for delay in road construction in Jordan. It is known that road construction involving a vast land of area. Any form of tough terrain makes the project more complicated to complete.

Project area characteristic seems to be not so significant in contributing to construction delay. This is probably due to the readiness and awareness of contractor about the site condition before the construction start.

Table 4: Importance of delay causes [15]

\begin{tabular}{|c|c|c|c|}
\hline No. & Owners & Contractors & Consultants \\
\hline 1 & Shortage of labours & Late payments by owner & Type of project bidding \\
\hline 2 & Unqualified workforce & Late in reviewing and approving & Labours shortages \\
\hline 3 & Ineffective planning and scheduling & Change orders by owner & Ineffective planning and scheduling \\
\hline 4 & Low productivity level of labours & Delays in producing design & Change orders by owner \\
\hline 5 & Hot weather & Late in review and approve design & Low productivity by labours \\
\hline 6 & Conflicts with subcontractors & Financing problem by contractor & Financing problem by contractor \\
\hline 7 & Poor site management and supervision & Design mistakes and discrepancies & Bad site management and supervision \\
\hline 8 & Inadequate contractors experience & Late materials procurement & Poor qualification of the contractors \\
\hline 9 & Subsurface conditions & Consultant inflexibility & Material delivery delay \\
\hline 10 & Change orders by owner & Owner making slow decision &
\end{tabular}

\section{Conclusions}

In relation to the topic discussed, a conclusion can be made regarding the importance of the type, location, and project area.
Table 3: Groups importance index [6]

\begin{tabular}{|c|c|c|}
\hline Rank & Delay group & $\begin{array}{c}\text { Group } \\
\text { importance } \\
\text { index }\end{array}$ \\
\hline 01 & Equipment related group & 0.752 \\
\hline 02 & Design related group & 0.739 \\
\hline 03 & Contractor related group & 0.728 \\
\hline 04 & Material related group & 0.723 \\
\hline 05 & Contract related group & 0.718 \\
\hline 06 & Consultant related group & 0.707 \\
\hline 07 & Financing related group & 0.699 \\
\hline 08 & Site-related group & 0.698 \\
\hline 09 & Scheduling and Controlling related group & 0.686 \\
\hline 10 & Owner related group & 0.680 \\
\hline 11 & Contractual relationship related group & 0.668 \\
\hline 12 & Labour related group & 0.665 \\
\hline 13 & Project related group & 0.660 \\
\hline 14 & External related group & 0.641 \\
\hline 15 & Rules \& regulations related group & 0.633 \\
\hline
\end{tabular}

For project type characteristic, it can be seen that major delay cause for building project is changing design during construction or change orders. As for infrastructure project, the main cause of delay is late contractor's payment by owner. Meanwhile, industrial project's primary cause is late delivery of materials. Obviously, 
different project type experienced different delay causes. This was probably due to different difficulties faced by each of project type. On the other hand, project location characteristic also undergoes the same pattern, which is within a region; they can be experienced almost the same pattern of major cause. Furthermore, the common causes faced by most regions are; late payment to contractors and design changes during construction.

Project area characteristic seems to be not so significant in contributing to construction delay. This is probably due to the readiness and awareness of contractor regarding the site condition before the construction start.

Therefore, the significant characteristics which influenced the construction delay are the project type and its location, while the project area characteristic is found to be insignificant, probably because it is more predictable. With this review's finding, hopefully, it can be guidance for a better understanding of the characteristics related to the construction delay problems, and can assist in producing comprehensive studies in the future.

\section{Acknowledgement}

The authors acknowledge Tenaga Nasional Berhad and Universiti Tenaga Nasional on the fund provided for this research. Special thanks to those who contributed to this project directly or indirectly.

\section{Reference}

[1] G. J. Sweis, R. Sweis, M. A. Rumman, R. A. Hussein, and S. E. Dahiya, "Cost Overruns in Public Construction Projects: The Case of Jordan," J. Am. Sci., vol. 9, no. 7, pp. 134-141, 2013.

[2] N. Hamzah, M. A. Khoiry, I. Arshad, N. M. Tawil, and A. I. Che Ani, "Cause of construction delay - Theoretical framework," Procedia Eng., vol. 20, pp. 490-495, 2011.

[3] M. Haseeb, A. Bibi, and W. Rabbani, "Causes and Effects of Delays in Large Construction Projects of Pakistan," Kuwait Chapter Arab. J. Bus. Manag. Rev., vol. 1, no. 4, pp. 18-42, 2011.

[4] R. F. Aziz, "Ranking of delay factors in construction projects after Egyptian revolution," Alexandria Eng. J., vol. 52, pp. 387-406, 2013.

[5] A. Arantes, P. F. Da Silva, and L. M. D. F. Ferreira, "Delays in construction projects - Causes and impacts," in Proceedings of 2015 International Conference on Industrial Engineering and Systems Management, IEEE IESM 2015, 2016.

[6] R. F. Aziz and A. A. Abdel-Hakam, "Exploring delay causes of road construction projects in Egypt," Alexandria Eng. J., vol. 55, no. 2, pp. 1515-1539, 2016

[7] N. Al-Hazim and Z. Abusalem, "Delay and cost overrun in road construction projects in Jordan," Int. J. Eng. Technol., vol. 4, no. 2 , pp. 288-293, 2015.

[8] M. Ruqaishi and H. A. Bashir, "Causes of Delay in Construction Projects in the Oil and Gas Industry in the Gulf Cooperation Council Countries: A Case Study," J. Manag. Eng., vol. 31, no. 3, p. 05014017, 2014

[9] M. H. Fallahnejad, "Delay causes in Iran gas pipeline projects," Int J. Proj. Manag., vol. 31, pp. 136-146, 2013.

[10] M. Gündüz, Y. Nielsen, and M. Özdemir, "Quantification of Delay Factors Using the Relative Importance Index Method for Construction Projects in Turkey," J. Manag. Eng., vol. 29, no. 2, pp 133-139, 2013.

[11] A. Kazaz, S. Ulubeyli, and N. A. Tuncbilekli, "Causes of Delays in Construction Projects in Turkey," J. Civ. Eng. Manag., vol. 18, no. 3, pp. 426-435, 2012.

[12] I. Mahamid, A. Bruland, and N. Dmaidi, "Causes of Delay in Road Construction Projects," J. Manag. Eng., vol. 28, no. 3, pp. 300-310, 2012.

[13] N. Hamzah, M. a Khoiry, I. Arshad, W. H. W. Badaruzzaman, and N. M. Tawil, "Identification of the causes of construction delay in Malaysia," World Acad. Sci. Eng. Technol., vol. 6, no. 12, pp. 1063-1068, 2012.

[14] C. Kaliba, M. Muya, and K. Mumba, "Cost escalation and schedule delays in road construction projects in Zambia," Int. J. Proj. Manag., vol. 27, pp. 522-531, 2009.
[15] S. A. Assaf and S. Al-Hejji, "Causes of delay in large construction projects,” Int. J. Proj. Manag., vol. 24, no. 4, pp. 349-357, 2006.

[16] W. Alaghbari, M. Razali A. Kadir, A. Salim, and Ernawati, "The significant factors causing delay of building construction projects in Malaysia," Eng. Constr. Archit. Manag., vol. 14, no. 2, pp. 192 206, 2007.

[17] S. O. Ogunlana, K. Promkuntong, and V. Jearkjirm, "Construction delays in a fast-growing economy: Comparing Thailand with other economies," Int. J. Proj. Manag., vol. 14, no. 1, pp. 37-45, 1996.

[18] M. Gunduz, Y. Nielsen, and M. Ozdemir, "Fuzzy Assessment Model to Estimate the Probability of Delay in Turkish Construction Projects," J. Manag. Eng., vol. 31, no. 4, p. 04014055, 2013.

[19] D. Arditi, G. T. Akan, and S. Gurdamar, "Reasons for delays in public projects in Turkey," Constr. Manag. Econ., vol. 3, no. 2, pp. $171-181,1985$

[20] A. Al-Kharashi and M. Skitmore, "Causes of delays in Saudi Arabian public sector construction projects," Constr. Manag. Econ., vol. 27, no. 1, pp. 3-23, 2009.

[21] S. A. Assaf, M. Al-Khalil, and M. Al-Hazmi, "Causes of Delay in Large Building Construction Projects," J. Manag. Eng., vol. 11, no. 2, pp. 45-50, 1995 .

[22] G. Sweis, R. Sweis, A. Abu Hammad, and A. Shboul, "Delays in construction projects: The case of Jordan," Int. J. Proj. Manag., vol 26, pp. 665-674, 2008.

[23] A. H. Al-Momani, "Construction delay: A quantitative analysis," Int. J. Proj. Manag., vol. 18, pp. 51-59, 2000.

[24] P. A. Koushki, K. Al-Rashid, and N. Kartam, "Delays and cost increases in the construction of private residential projects in Kuwait," Constr. Manag. Econ., vol. 23, pp. 285-294, 2005

[25] P. F. Kaming, P. O. Olomolaiye, G. D. Holt, and F. C. Harris, "Factors influencing construction time and cost overruns on highrise projects in Indonesia," Constr. Manag. Econ., vol. 15, no. 1, pp 83-94, 1997.

[26] P. Ahmed, S.M., Azhar, S., Castillo, M. and Kappagantula, "Construction delays in Florida: An empirical study. Final report.,' Florida, US, 2002

[27] M. I. Al-Khalil and M. A. Al-Ghafly, "Important causes of delay in public utility projects in Saudi Arabia," Constr. Manag. Econ., vol. 17, pp. 647-655, 1999.

[28] N. Mansfield, O. Ugwu, and T. Doran, "Causes of delay and cost overruns in Nigerian construction projects," Int. J. Proj. Manag., vol. 12, no. 4, pp. 254-260, 1994.

[29] Y. Frimpong, J. Oluwoye, and L. Crawford, "Causes of delay and cost overruns in construction of groundwater projects in a developing countries; Ghana as a case study," Int. J. Proj. Manag., vol. 21, pp. 321-326, 2003.

[30] M. Salama, M. Abd El Hamid, and B. Keogh, "Investigating the causes of delay within oil and gas projects in the UAE," in Proceedings of the 24th Annual ARCOM Conference, 2008, pp. 819-827.

[31] H. Abdul-Rahman, M. A. Berawi, A. R. Berawi, O. Mohamed, M. Othman, and I. A. Yahya, "Delay Mitigation in the Malaysian Construction Industry," J. Constr. Eng. Manag., vol. 132, no. 2, pp. 125-133, 2006.

[32] M. Sambasivan and Y. W. Soon, "Causes and effects of delays in Malaysian construction industry," Int. J. Proj. Manag., vol. 25, no. 5, pp. 517-526, 2007.

[33] A. S. Faridi and S. M. El-Sayegh, "Significant factors causing delay in the UAE construction industry," Constr. Manag. Econ., vol. 24, pp. 1167-1176, 2006.

[34] M. Kadry, H. Osman, and M. Georgy, "Causes of construction delays in countries with high geopolitical risks," J. Constr. Eng. Manag., vol. 143, no. 2, pp. 1-11, 2016.

[35] EY, "Spotlight on oil and gas megaprojects." 2014.

[36] D. Arditi, S. Nayak, and A. Damci, "Effect of organizational culture on delay in construction," Int. J. Proj. Manag., vol. 35, no. 2, pp. 136-147, 2017.

[37] A. M. Odeh and H. T. Battaineh, "Causes of construction delay: traditional contracts," Int. J. Proj. Manag., vol. 20, no. 1, pp. 67-73, Jan. 2002.

[38] M. E. Abd El-Razek, H. A. Bassioni, and A. M. Mobarak, "Causes of Delay in Building Construction Projects in Egypt," J. Constr. Eng. Manag., vol. 134, no. 11, pp. 831-841, 2008.

[39] T. M. Mezher and W. Tawil, "Causes of delays in the construction industry in Lebanon," Eng. Constr. Archit. Manag., vol. 5, no. 3, pp. 252-260, 1998

[40] J.-B. Yang and P.-R. Wei, "Causes of Delay in the Planning and Design Phases for Construction Projects," J. Archit. Eng., vol. 16, 
no. 2 , pp. 80-83, 2010

[41] T. Y. Lo, I. W. Fung, and K. C. Tung, "Construction Delays in Hong Kong Civil Engineering Projects," J. Constr. Eng. Manag., vol. 132, no. 6, pp. 636-649, 2006.

[42] D. W. Chan and M. M. Kumaraswamy, "A comparative study of causes of time overruns in Hong Kong construction projects," Int. J. Proj. Manag., vol. 15, no. 1, pp. 55-63, 1997.

[43] D. W. M. Chan and M. M. Kumaraswamy, "A study of the factors affecting construction durations in Hong Kong," Constr. Manag. Econ., vol. 13, pp. 319-333, 1995.

[44] S. U. R. Toor and S. Ogunlana, "Problems causing delays in major construction projects in Thailand," Constr. Manag. Econ., vol. 26, pp. 395-408, 2008.

[45] A. A. Aibinu and H. A. Odeyinka, "Construction Delays and Their Causative Factors in Nigeria," J. Constr. Eng. Manag., vol. 132, no. 7, pp. 667-677, 2006.

[46] M. M Dlakwa and M. F Culpin, "Reasons for overrun in public sector construction projects in Nigeria," Int. J. Proj. Manag., vol. 8, no. 4, pp. 237-241, 1990.

[47] R. B. Baldwin, J.R., Manthei, J.M., Rothbart, H. and Harris, "Causes of delay in the construction industry," J. Constr. Div., vol. 97, no. 2, pp. 177-187, 1971.

[48] C. Semple, F. T. Hartman, and G. Jergeas, "Construction claims and disputes: Causes and cost/time overruns," J. Constr. Eng. Manag., vol. 120, no. 4, pp. 785-795, 1994.

[49] R. D. Lewis and M. Gates, When Cultures Collide: Leading Across Cultures. Nicholas Brealey, 1996. 